\title{
Development of well reception to reduce rain surface surface in Sunggal village right Deli Serdang district
}

\author{
J. Tarigan $^{1 *}$, Roesyanto ${ }^{1}$, R.A. Sembiring ${ }^{1}$, M.A. Pulungan ${ }^{1}$,A. Ananta ${ }^{1}$ \\ ${ }^{1}$ Department of Civil Engineering, Faculty of Engineering, Universitas Sumatera Utara, \\ Medan, Indoensia \\ *Email: geasyafridon@yahoo.com
}

\begin{abstract}
Water catchment areas are very important to reduce surface runoff that enters the drainage, but the rise of housing development results in damage to the water catchment area. Development of settlements, offices, educational buildings, and other buildings often do not pay attention to areas that should be open green land. Land cover causes a large infiltration to be reduced when it rains, thereby increasing surface runoff which can result in inundation or flooding. One village that is increasingly crowded with settlements is the right sunggal village in the Deli Serdang district. The main problem in the village of Sunggal Kanan, especially the Gusti Wijaya University Foundation, which is a service partner, is the lack of open land in the foundation complex as a water catchment zone. The solution offered in this program is in the form of infiltration well construction. This method utilizes wells as a water catchment container when it rains. With this infiltration well, rainwater runoff can be reduced.
\end{abstract}

Keywor d: Wells, Infiltration, Flooding, Inundation, Settlement.

\begin{abstract}
Abstrak
Kawasan resapan air sangat penting untuk mengurangi limpasan permukaan yang masuk ke drainase, namun maraknya pembangunan perumahan mengakibatkan rusaknya kawasan resapan air tersebut. Pembangunan pemukiman, perkantoran, gedung pendidikan, dan bangunan lainnya sering kali tidak memperhatikan wilayah yang seharusnya menjadi lahan terbuka hujau. Tutupan lahan menyebabkan besar infiltrasi menjadi berkurang ketika hujan, sehingga memperbesar limpasan permukaan yang dapat mengakibatkan terjadinya genangan atau banjir. Salah satu desa yang semakin dipadati pemukiman adalah desa sunggal kanan yang berada di kabupaten deli serdang. Permasalahan utama pada Desa Sunggal Kanan khususnya Yayasan Perguruan Gusti Wijaya yang menjadi mitra pengabdian adalah sangat minimnya lahan terbuka di komplek yayasan sebagai zona resapan air. Solusi yang ditawarkan pada program ini berupa pembangunan sumur resapan. Metode ini memanfaatkan sumur sebagai wadah resapan air ketika hujan. Dengan adanya sumur resapan ini, maka limpasan permukaan air hujan dapat tereduksi.
\end{abstract}

Kata Kunci: Sumur, Resapan, Banjir, Genangan, Pemukiman.

\section{PENDAhuluan}

Sasaran dari Program Pengabdian Kepada Masyarakat adalah masyarakat umum yang berada di kawasan Desa Sunggal Kanan, Kecamatan Sunggal yang merupakan wilayah pemukiman yang beberapa kali dilanda banjir. Salah satu penyebab terjadinya banjir adalah cepatnya perubahan tataguna lahan di Kecamatan Sunggal dari wilayah pertanian menjadi wilayah pemukiman padat penduduk. Pemabangunan perumahan mengakibatkan terjadinya perubahan pada penggunaa lahan, selain itu kawasan resapan air juga dirusak secara tidak langsung. Kawasan resapan air sangat penting untuk mengurangi limpasan permukaan yang masuk ke drainase. Pembangunan pemukiman, perkantoran, gedung pendidikan, dan bangunan lainnya sering kali tidak memperhatikan wilayah yang seharusnya menjadi lahan terbuka hijau.

Yayasan Perguruan Gusti Wijaya yang terdapat di Desa Sunggal Kanan merupakan salah satu wilayah yang seharusnya menjadi lahan terbuka hijau. 


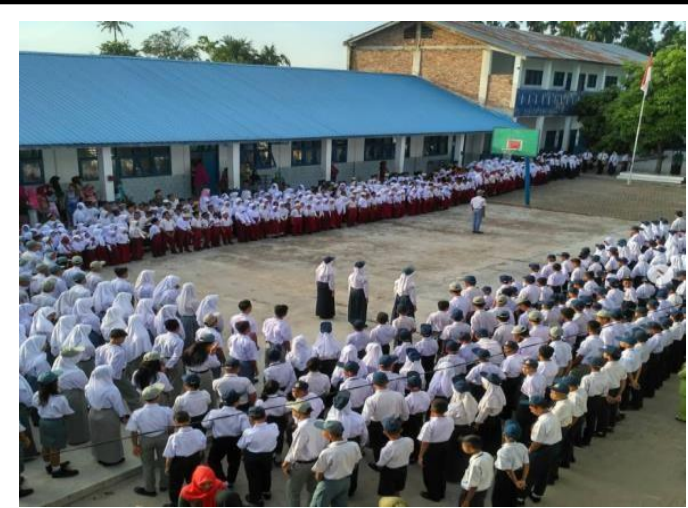

Gambar 1.1. Kondisi lahan Yayasan Perguruan Gusti Wijaya

Pada Gambar 1.1. terlihat lahan yayasan hampir seluruhnya tertutup dengan gedung dan halamannya tertutup oleh beton dan paving block. Hal ini menyebabkan besar infiltrasi menjadi berkurang ketika hujan, sehingga memperbesar limpasan permukaan.

Akibat tidak adanya wilayah resapan air, persediaan air tanah menjadi semakin tipis dan juga terjadi ketidakstabilan kondisi air seperti kelebihan air di musim penghujan dan kurangnya air di musim kemarau. Kelebihan air di musim penghujan menyebabkan banjir dan kekuranga air di musim kemarau menyebabkan masyarakat susah untuk mendapatkan air bersih.

Salah satu upaya yang dapat digunakan untuk meresapkan air hujan adalah dengan membuat sumur resapan. Dengan adanya sumur resapan, air hujan yang turun langsung di resapkan kedalam tanah dan secara otomatis akan menambah persediaan cadangan air tanah. Sumur resapan berfungsi untuk mengurangi aliran dipermukaan dan genangan banjir, menambah potensi air tanah, mencegah penurunan tanah, dan mengurangi meluasnya penyusupan/instrusi laut kearah daratan, Sumur resapan adalah sistem resapan buatan, yang dibuat untuk menampung air hujan akibat penutupan permukaan tanah oleh bangunan. Pada musim hujan debit aliran tinggi, sedangkan pada musim kemarau debit aliran sangat rendah bahkan kering. Menyimpan air pada musim hujan dengan menggunakan sumur resapan merupakan salah satu solusi yang efektif, untuk menekan besaran debit. Air tanah yang berlebih saat musim hujan akan membantu memenuhi kebutuhan air pada saat kekeringan dimusim kemarau dalam bentuk air aliran base flow.

\section{METODE PELAKSANAAN}

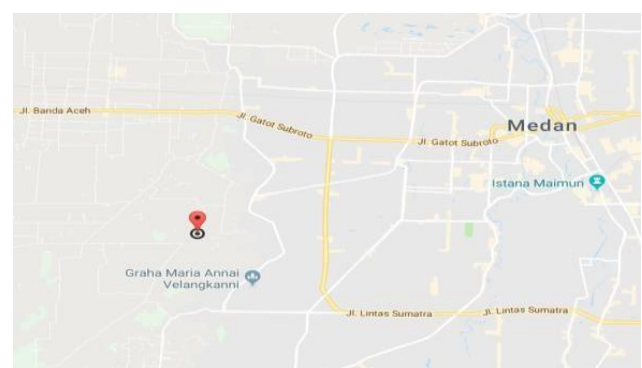

Gambar 2.1. Lokasi program pengabdian kepada masyarakat

Pengadian kepada masyarakat pada Program Pengabdian kepada Masyarakat Univirsitas Sumatra Utara untuk mono tahun dilakukan di Yayasan Perguruan Gusti wijaya, desa Sunggal Kanan Kabupaten Deli Serdang. Kegiatan pengabdian yang dilakukan berupa pembangunan sumur resapan untuk mereduksi limpasan permukaan air hujan. Pembangunan sumur resapan dilakukan oleh kolaborasi antara tim pengabdian, mahasiswa Universitas Sumatra Utara, dan masyarakat setempat. Adapun tahapan yang dilakukan adalah sebagai berikut.

2.1 Studi literatur

Pencarian literatur untuk menentukan metode yang efektif sesuai dengan permasalahannya. 


\subsection{Tahap analisis}

Perencanaan lokasi sumur dan dimensi sumur resapan dan talang air yang sesuai. Tahapan analisa adalah sebagai berikut:

1) Menentukan lokasi sumur

Pilih titik lokasi sumur resapan air hujan yang akan dibangun di lahan sekitar pekarangan Yayasan Perguruan Gusti wijaya dengan luasan yang cukup untuk membuat satu sunur resapan.

2) Pengukuran jarak sumur resapan

Ukur jarak antara rencana titik lokasi sumur resapan air hujan yang akan dibangun dengan bangunan terdekat.

3) Pengukuran muka air tanah

Ukur kedalaman muka air tanah di titik lokasi yang akan dibangun summur resapan. Apabila kedalaman muka air tanah>2 m, maka sumur resapan dapat dibuat.

4) Penentuan angka permeabilitas tanah

Uji permeabilitas tanahdi kedalaman 2-3 meter. Apabila nilai koefisien permeabilitas tanah $>2,0 \mathrm{~m} / \mathrm{jam}$, maka sumur resapan air dapat dibuat.

5) Perhitungan dimensi sumur

Data yang dibutuhkan untuk menghitung dimensi sumur adalah sebagai berikut:

a) curah hujan harian 5 tahunan untuk menghitung nilai intensitas hujan (i), b) luas bidang tanah yang berfungsi sebagai pengumpul air hujan, c) jenis tanah (nilai koefesien permeabilitas tanah) di lokasi rencana pembangunan sumur resapan, d) koefisien limpasan air hujan (c) di lokasi rencana pembangunan sumur resapan.

Dari data diatas, dimensi sumur resapan air hujan dihitung dengan menggunakan rumus-rumus berikut:

1) perhitungan intensitas hujan

2) penentuan koefisien limpasan (c) pada bidang tadah, gunakan nilai 0,95.

3) Perhitungan kedalaman sumur resapan.

Adapun langkah-langkah analisa perencanaan tersebut dapat dilihat pada Gambar 2.2.

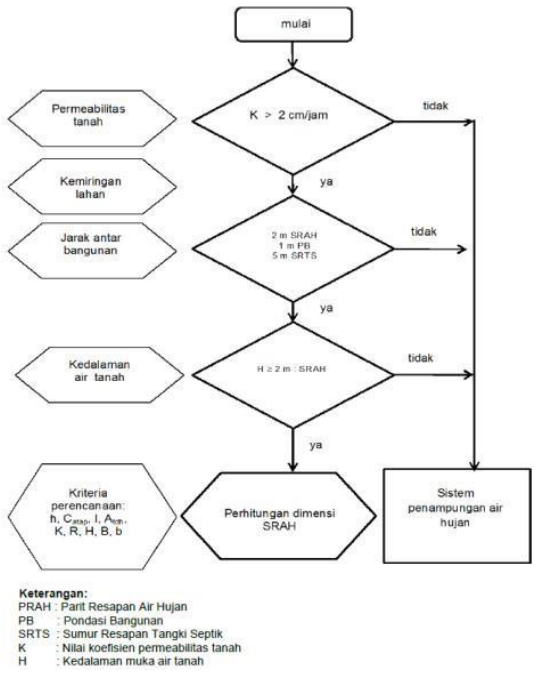

Gambar 2.2. Diagram alir langkah-langkah perencanaan sumur resapan

2.3 Persiapan alat dan bahan

Bertujuan untuk mempersiapkan peralatan dan material yang diperlukan saat pembuatan sumur resapan. Alat dan materialnya disesuaikan dengan lokasi pengabdian.

2.4 Pembangunan sumur resapan

\section{HASIL DAN PEMBAHASAN}


Program pengabdian kepada masyarakat berupa pembangunan sumur resapan air hujan ini dilaksanakan pada bulan april sampai bulan september 2019 di Yayasan Perguruan Gusti Wijaya. Semua tahapan kegiatan pengabdian oleh tim pengabdian dan mahasiswa yang dilibatkan pada kegiatan pengabdian tersebut. Kegiatan juga dibantu oleh masyarakat setempat dalam proses pembuatan sumur resapan air hujan.

Kegiatan pengabdian ini berlangsung selama beberapa minggu yang dikerjakan oleh beberapa tukang dan diawasi oleh tim pengabdian dan masyarakat setempat. Kerjasama antara tim pengabdian dengan masyarakat sekitar sangat membantu dalam penyelesaian pembuatan sumur resapan dengan tepat waktu sehingga dengan segera bisa berfungsi menampung limpasan air hujan.

Gambar-gambar berikut merupakan dokumentasi pelaksanaan pengabdian kepada masyarakat dari awal kegiatan yaitu rapat koordinasi dengan masyarakat setempat sampai dengan tahap pembangunan sumur resapan air hujan.

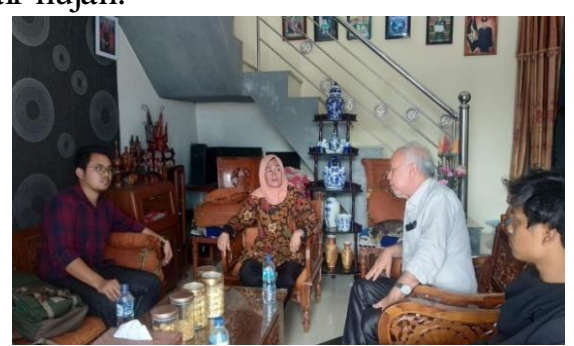

Gambar 3.1. Rapat tim pengabdian masyarakat dengan koordinator masyarakat setempat

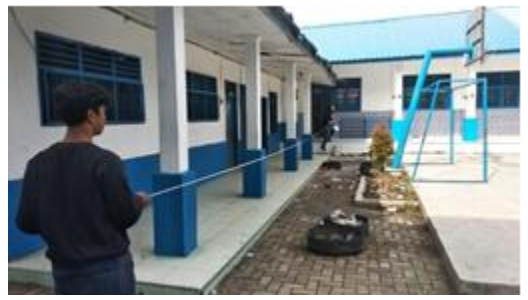

Gambar 3.2. Pengukuran luas permukaan tanah yang tertutupi oleh bangunan

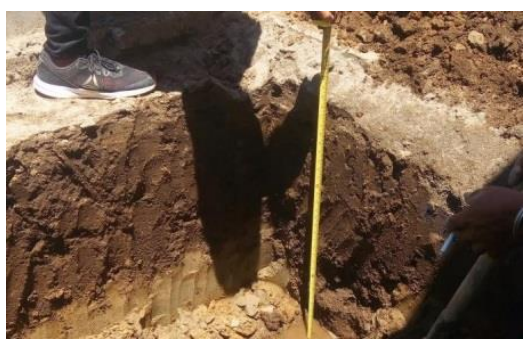

Gambar 3.3. Proses penggalian sumur resapan air hujan

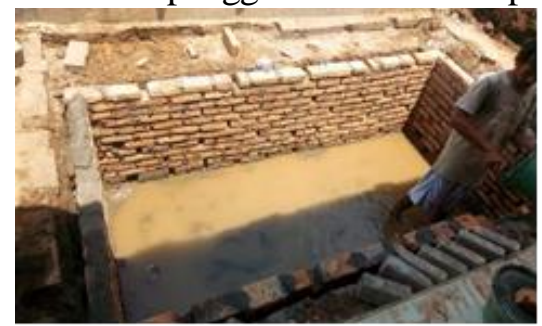

Gambar 3.4. Pemasangan dinding sumur resapan air hujan 


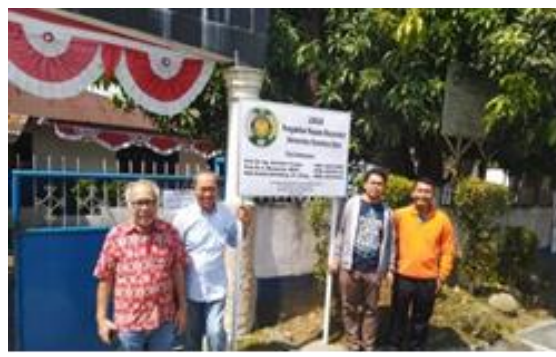

Gambar 3.5. Tim pengabdian bersama dengan perwakilan dari masyarakat

\section{KESIMPULAN}

Pembuatan sumur resapan dari program pengabdian kepada masyarakat di Yayasan Perguruan Gusti Wijaya, desa sunggal kanan sudah dapat dinikmati secara langsung oleh masyarakat sekitar sekolah. Sumur resapan yang dibangun sudah dapat menampung sejumlah air hujan sehingga mengurangi debit limpasan air hujan.

\section{UCAPAN TERIMAKASIH}

Tim pengabdian pada masyarakat mengucapkan terima kasih kepada pihak LPPM USU yang telah memberikan dana kepada pengabdian ini. Terima kasih juga kepada pihak mitra yang telah koopratif di dalam pelaksanaan pengabdian ini.

\section{DAFTAR PUSTAKA}

Artati, N. 2013. Perancangan Alat Perajang Umbi-Umbian dengan Metode Quality Function Development (QFD). Jurnal Teknik Industri STT Wiworotomo. Purwokerto.

Astawan, M. \& Mita, W. 1991. Teknologi Pengolahan Pangan Nabati Tepat Guna. Jakarta: Akademika Pressindo.

Cross, Nigel. 1996. Engineering Design Methods: Strategies for Product Design. New York: John Wiley dan Sons

Ginting, R. 2009. Perancangan Produk. Yogyakarta: Graha Ilmu

Kristanto, Agung. 2015. Perancangan Ulang Alat Perontok Padi yang Ergonomis untuk Meningkatkan Produktivitas dan Kualitas Kebersihan Padi. Yogyakarta: Universitas Ahmad Dahlan

Yahya, Idhar. 2016. Perbaikan Fasililitas Produksi Meningkatkan Pendapatan Perajin Tape Manis. Medan. Abdimas Talenta 1 